\title{
İmam Hatip Lisesi Öğrencilerinin Akran İlişkilerinin İnsanî Değerler ve Öznel İyi Oluş Düzeyleri Açısından İncelenmesi
}

\author{
Doç. Dr. Seval ERDEN* \\ Marmara Üniversitesi, Eğitim Fakültesi, Göztepe Kampüsü, Kadıköy / İstanbul / Türkiye
}

\section{Saliha YILMAZ}

M. Emin Saraç İmam Hatip Lisesi, Başakşehir / İstanbul / Türkiye

\section{$\ddot{\mathbf{O z}}$}

$\mathrm{Bu}$ araştırma Anadolu imam hatip lisesi öğrencilerinin akran ilişkilerinin insanî değerler ve öznel iyi oluş düzeyleri açısından incelenmesini amaçlamaktadır. Araştırma nicel araştırma desenlerinden ilişkisel tarama modelinde oluşturulmuştur. Araştırmada olasıllk temelli örnekleme yöntemlerinden küme örnekleme yöntemi kullanılmıştır. Araştırmanın çalışma grubunu, 2014-2015 eğitim-öğretim yılında İstanbul ilinde Anadolu imam hatip liselerinde öğrenim görmekte olan 543'ü (\%64.8) k1z; 295'i (\%35.2) erkek olmak üzere toplam 838 lise öğrencisi oluşturmuştur. Elde edilen veriler SPSS 15.0 programı ile analiz edilerek tablolar hâlinde sunulmuştur. Analizlerde akran ilişkilerinin öznel iyi oluş ve insanî değerlerle ilişkisi; akran ilişkileri, öznel iyi oluş ve insanî değerlerin cinsiyet, sınıf düzeyi, anne-baba eğitim 
durumuna göre anlamlı farklılık gösterip göstermediği incelenmiştir. Araştırma sonucunda öznel iyi oluş puanları ile "Bağlılık, Güven ve Özdeşim” alt boyutları, akran ilişkileri toplam puan arasında pozitif; "Sadakat" alt boyutu arasında negatif yönde anlamlı bir ilişki olduğu bulunmuştur. İnsanî değerler toplam puanları ve alt boyutlarının akran ilişkileri "Bağlılık" alt boyutu ile arasında pozitif; akran ilişkileri "Sadakat" alt boyutu arasında negatif yönde anlamlı bir ilişki olduğu bulunmuştur. Akran ilişkileri "Bağlılık ve Kendini Açma" alt boyutlarında kız öğrencilerin, "Sadakat" alt boyutunda erkek öğrencilerin lehine; insanî değerler "Dostluk/Arkadaşlık, Barışçı Olma ve Dürüstlük” alt boyutlarında kız öğrencilerin lehine anlamlı bir farklılık olduğu tespit edilmiştir. İnsanî değerler toplam, "Sorumluluk ve Barışçı Olma" alt boyutunun anne eğitim düzeyi azaldıkça arttı̆̆ı; insanî değerler "Sorumluluk ve Saygı" alt boyutu ise baba eğitim düzeyi azaldıkça arttığı tespit edilmiştir.

Anahtar Kelimeler: Öznel iyi oluş; İnsanî değerler; Akran ilişkileri; İmam hatip lisesi.

\title{
Examining the Peer Relationships of Imam Hatip High School Students in Terms of Human Values and Subjective Well-Being Levels
}

\begin{abstract}
The aim of this study is to examine the peer relationships of Imam Hatip High School students in terms of human values and subjective well-being levels. The study was prepared according to the relational screening model, a subtype of quantitative research patterns. The cluster sampling method from probability based sampling methods was used in this study. In the analysis, it was investigated the relationship between peer relations and subjective well-being and human values. Moreover the effect of gender, grade and educational levels of parents were also investigated in accordance with the aim.
\end{abstract}

Keywords: Subjective well-being; Human values; Peer relationship; Imam hatip high school. 


\section{Extended Summary}

The purpose of the study was to examine the peer relationships of imam hatip high school students in terms of human values and subjective well-being levels. In accordance with the main aim, students' peer relationships, human values and their subjective well-being were also investigated in terms of variables such as gender, grade and educational levels of parents.

\section{Purpose}

The purpose of this study is to analyze the change by observing the perspectives of students in the study group. Based on this general aim, this study intends to designate the views of students on new appearance regime in schools according to aspects of democratization, sense of belonging to the school, period of change, socio-economic level and personal image development.

\section{Method}

The study was prepared according to the relational screening model, a subtype of quantitative research patterns. The cluster sampling method from probability based sampling methods was used in this study. The study group consisted of 543 female students (64.8\%) and 295 male students (35.2\%), or 838 high school students in total, studying at Anadolu Imam Hatip High Schools in Istanbul during 2014-2015 academic year.

Subjective Well-Being Scale, Human Values Scale, Peer Relationship Scale and Personal Information Form were used for collecting data. The obtained data was analyzed via SPSS 15.0 programme. In order to analyze the relationships among variables, the Pearson Product-Moment Correlation Coefficient technique, and to examine the effects of demographic variables the Independent Samples t Test, the Mann-Whitney U Test, the One-Way Analysis of Variance (ANOVA), and the Kruksal Wallis-H Test were applied in this study.

\section{Results}

Examining the relation between peer relationships and subjective well-being, it was found that there was a positively significant relationship between the total scores of peer relationships and the subjective well-being scores and its "Loyalty, Trust and Identification" sub-dimensions; whereas, 
there was a negatively significant relationship with "Fidelity" sub-dimension. Investigating the relation between peer relationships and human values, it was found that there was a positively significant relationship between human values and "Loyalty" sub-dimension of peer relationship; whereas, there was a negatively significant relationship with "Fidelity" sub-dimension.

When the results were examined in terms of gender, it was found that there was a significant difference between total scores of peer relationship and "loyalty and self-disclosure" sub-dimensions in favor of female students; and for "loyalty" sub-dimension in favor of male students. There was also a significant difference between human values "friendship, respect and honesty" sub-dimensions and total scores of students in favor of female students. In terms of grade, it was determined that the more grade level decreases, the more peer relationship "trust and identification" sub-dimensions increases; the more grade levels increases, the more "self-disclosure" sub-dimension increases; the more grade levels increases, the more human values "honesty" sub-dimension increases. On the other hand, parents' education had an effect.

It was ascertained that the more peer relationship "loyalty" sub-dimension of students increases, the more educational levels of parents increases. Furthermore the students having elementary school graduated parents are relatively more disadvantaged than the students having higher education graduated parents in the context of peer relationship "loyalty" sub-dimension.

\section{Discussion}

In the studies comparing happy and unhappy people, it was stated that the happy people had more qualified friends and stronger social relationships than unhappy ones (Diener, Diener and Tamir, 2004). In the research about high school students and the relationship between their subjective well-being levels and social skills levels, Canbay (2010) determined that there was a positive and significant relationship between subjective well-being and social skills.

In another research conducted on eighth grade students studying at regional primary boarding school and students living with their families, with the aim of examining their peer relationships (Şimşek, 2010), the results 
showed that female students had significantly higher "loyalty and self-disclosure" scores then male students. In his study about examination of peer relationships of physically disabled adolescents and healthy adolescents, Çömez (2014) stated that female adolescents had significantly higher "loyalty" sub-dimension scores than male students.

Screening the literature, it was found that there was not a significant relationship between subjective well-being of individuals and gender variable (Çelik, 2008; Dost, 2005; Saygın, 2009; Şahin, 2011). In their study about adolescents, Dereli and Alpay (2011) found that human values such as "friendship, peacefulness, honesty and respect" average scores were significantly different in favor of female students.

In the study of examining the peer relationships of adolescents according to gender, parental attitudes and educational levels of parents, Büyükşahin, Çevik and Çelikkaleli (2010) ascertained that adolescents' friendship commitment scores did not significantly differ to the educational level of mother; however it significantly differed to the educational level of father. In their study focused on how empathic tendency and cooperation, personality traits predict the level of human values. In the other study, Dereli and Alpay (2011) found that parents' education levels affect values especially "peacefulness" and "responsibility".

\section{Conclusion}

It is thought that this study will contribute future preventive actions for teachers, school counselors and administrators by adopting an open, democratic and supportive communication styles towards students and to be knowledgeable about peer relationships, human values, and subjective well-being and make the students and parents knowledgeable about these topics.

It is certain that applying the obtained results from this study to larger sample groups and schools from different socio-economic levels will not only increase the validity of this research and also contribute to the literature. In another aspect, it might be possible to build up a detailed profile about what the perceptions of students are on the variables of research with using a qualitative research method. Besides, it is thought that it will be beneficial to 
be supported by experimental studies.

\section{Giriş}

Çocukluktan erişkinliğe geçiş dönemi olarak nitelendirilen ergenlik dönemi hızlı fiziksel, duyuşsal, bilişsel ve sosyal değişimlerle karakterize bir dönemdir. Bu dönemde ergenin fiziksel özelliklerini kabul etmek, cinsiyet rolüne uygun davranışlar geliştirmek, duygusal bağımsızlığını kazanmak, arkadaşlık becerileri edinmek, kendini tanımak, mesleğe ve aile yaşamına hazırlanmak, kimlik kazanımı, davranışlarına kılavuzluk eden ahlakî bir sistem geliştirmek gibi gelişim görevlerini yerine getirmesi beklenmektedir (Santrock, 2011).

Her iki cins akranlarıyla daha olgun ilişki kurabilmesi istenen ergen, erken dönemde oluşturduğu zihinsel modelleri akran ilişkilerine transfer eder. $\mathrm{Bu}$ dönemde ailenin verdiği destek, bilgi ve beceriler artık ergenin ihtiyaç, istek ve gereksinimlerini karşılayabilecek nitelikte algılanmaması nedeniyle ergen, destekleyici yeni ilişkilere ihtiyaç duymaktadır. Bu nedenle bağlanma modeli akranlar ya da en iyi arkadaştır (Erden-İmamoğlu, 2009).

Yapılan çalışmalar, arkadaşlığın psikolojik iyi oluşta ve hayat stresini azaltmada önemli bir etken olduğunu göstermiştir (Cüceloğlu, 1992). Eryılmaz ve Yorulmaz (2006) yaptıkları araştırmada ergenlerin mutlu olmak için insanlarla olumlu ilişkiler içinde olmayı, saygı ve sevgi göstermeyi, olumlu akademik deneyime sahip olmayı, olumsuz duyguları kontrol etmeyi kullandıkları sonucuna varmışlardır.

Akran ilişkileri ergenlik döneminde ahlakî norm ve insanî değerlerinin kazanılmasına, gruptaki geribildirimlerle ilişki kurma becerilerinin gelişimine de katkı sağlamaktadır. Aynı zamanda arkadaş grupları sadakat, cesaret, dürüstlük, güven, sorumluluk değerlerinin kazanıldığı ortamlar olarak da işlev görmektedir (Döğücü, 2004).

\section{Akran İlişkileri}

Kimlik bunalımı, özerklik, fizyolojik ve duygusal değişimler ve buna bağlı olarak duygusal iniş çıkışlar, yeni ve farklı ilişkiler, ergenin kişiler arası ilişkilerinde de farklılık yaratmaktadır (Santrock, 2011). Bu geçiş dönemini başarılı bir şekilde atlatan ergenleri, problem yaşayan ergenlerden 
ayıran en önemli özellik, ergenlerin hem ebeveynleriyle hem de akranlarıyla oluşturduğu ilişkilerin niteliğidir (Şimşek, 2010).

Köknel (1997)'e göre akran ilişkileri, hayatın her safhasında ihtiyaç duyulan, iletişim ve etkileşim gruplarının bütün vasıflarını taşıyan, ortak tutum ve davranış kalıplarının geliştiği, yeni davranış ve tutumların oluşturulduğu, değerlerin paylaşıldığı en küçük toplumsal birimdir. Başka bir ifadeyle akran ilişkileri, belirli bir yaş düzeyinde ya da aynı gelişim aşamasında olan, birbirine yakın yaşantı, geçmiş, değer, sosyal ortam ve hayat tarzı açısından aynı paydada buluşan bireyler arasındaki karşılıklılık ve süreklilik arz eden etkileşim ve iletişimlerin bütünüdür (Gülay, 2009).

Yapılan çalışmalar da sağlıklı akran ilişkilerinin, ergeninin uyum sağlama (Şimşek, 2010), benlik saygısı geliştirme (Büyükşahin-Çevik, 2007), başarı ve mutluluk düzeyini arttırma (Sayıl, Uçanok ve Güre, 2002), romantik ilişkileri deneyimleme (Demir, Baran ve Ulusoy, 2005), aileye bağlanma (Hortaçsu ve Oral, 1991), sosyal beceri kazanma (Bilgiç, 2000; Çömez, 2014), güven ve değerli olma duygusunu hissetme (Totan, 2008) gibi duygusal ve sosyal gelişime olumlu katkı sağladığı ortaya konmuştur. Öte yandan sağlıklı akran ilişkileri kuramamanın, fiziksel şiddet ve öfke, sosyal yal1tım (Bilgiç, 2000; Yücel, 2009), zorbalık (Totan, 2008), sosyal beceride zayıflık (Uz-Baş ve Siyez, 2006), okul başarısında düşüş ve aile ilişkilerinde çatışma (Sayıl, Uçanok ve Güre, 2002) ile ilişkili olduğu da görülmektedir.

\section{Öznel İyi Oluş}

Öznel iyi oluş kavramı pozitif psikoloji ile birlikte ele alınmıştır. Pozitif psikoloji bireylerin, grupların ve kurumların var olan potansiyellerini, güçlü ve olumlu yönlerini en etkin ve verimli bir şekilde ortaya koymasını sağlayan ve olumlu yönde gelişimlerini destekleyen durumların neler olduğunu inceleyen bir psikoloji disiplinidir (Gable ve Haidt, 2005, akt; Malkoç, 2011).

Diener'e (2000) göre öznel iyi oluş “bireyin bilişsel ve duyuşsal olarak kendi yaşamını değerlendirmesi"dir ve sübjektiftir. Duygulanım boyutu, negatif duygulanım (öfke, üzüntü, suçluluk gibi) ve pozitif duygulanımdan (sevinç, heyecan, güven gibi) oluşmaktadır ve bireyin mutluluğuna, iyi oluşuna işaret etmektedir. Bilişsel boyut bireyin çeşitli hayat alanlarındaki doyumuna ilişkin değerlendirmelerini içerir (Diener, 1984). Birey hayatından 
doyum alıyorsa, olumlu duyguları sıklıkla ve olumsuz duyguları daha az yaşıyorsa, öznel iyi oluş düzeyinin yüksek olduğu anlamına gelir (Aypay ve Eryılmaz, 2011).

Öznel iyi oluş kavramını açıklayan farklı kuramsal yaklaşımlar ortaya konmuştur. Bunlardan biri erek kuramıdır. İlk defa Wilson (1967) tarafindan ortaya atılan kurama göre mutluluk, hedeflere ulaş1lıp gereksinimlerin karş1lanması ile elde edilir. Buna göre doyurulan gereksinimler mutlu olmayı sağlarken, karşılanmayan gereksinimler ise mutsuzluğa yol açmaktadır. Diener (1984) tarafından geliştirilen uyum kuramına göre olaylar ilk oluştukları anda olumlu ya da olumsuz oluşlarına göre kişide mutluluk ya da mutsuzluk hissi oluşturacağını ancak ilerleyen zamanlarda ilk zamanda oluşturdukları etkiyi yitireceklerini, alışma sürecinin gerçekleşeceğini ifade etmektedir. Ryff' in psikolojik iyi oluş kuramına göre ise psikolojik iyi oluş diğer kişilerle kurulan olumlu ilişkileri, yüksek düzeydeki benlik saygısını, sosyal beceriyi, bir birey olarak bağımsız hareket edebilmeyi, hayata anlam yüklemeyi ve amaçlar edinmeyi içerir (Ryff, 1989, akt; Malkoç, 2011).

\section{İnsanî Değerler}

İnsanlık, insanî değerleri yeniden keşfetme aşamasına gelmiştir. Yüksek teknolojinin otomatikleştirdiği insan, bir çıkış noktası aramaktadır. Bu çıkışın yolu, bilgi ve hedefi, insanî değerlerdir (Fındıkçı, 1998). Değerler, insanların bütün hayatı süresince davranışlarını yönlendirmede, açıklamada etkili olan ve hayatının, kişiliğinin şekillenmesinde rol oynayan ögeler olmas1 sebebi ilen birçok sosyal bilimci tarafından daima ilgi çekmiş ve merak konusu olmuştur (Ekşi, 2003; Yel ve Aladağ, 2009). Bununla birlikte değerler, birçok değişik disiplinlere girmiş olması ve diğer değişkenlerle olan ilişkileri bugüne kadar araştırılmış olmasına rağmen değerlerin tam olarak neyi içerdiğine ilişkin henüz bir netlik kazandığını söylememiz zordur (Bacanlı, 2002; Mehmetoğlu, 2006).

TDK (b.t.)'ye göre değer, bir şeyin önemini belirlemeye yarayan soyut ölçü, bir şeyin değdiği karşılık, kıymet. İlke olarak değerler, bireylerin nasıl davranması gerektiğine rehberlik ederken; kavramsal olarak, "olması gerekeni” ifade eder (Bolay, 2004). Değerler, bireyin çevresi ile etkileşimi sonucunda içselleştirdiği ve davranışlarını yönlendiren standartlar olarak da tanımlanmıştır (Akbaş, 2004). 
Bireyin aile yaşantısıyla başlayıp okulla birlikte gelişmeye devam eden, kişilik gelişiminde temel bir öneme sahip olan insanî değerler, bireyin yaptıklarının sorumluluğunu almasını, arkadaşlarıyla olumlu, açık bir iletişim kurabilmesini, insanlarla barışık bir şekilde yaşamasını, saygılı ve dürüst olmasını, anlayışlı ve hoşgörülü tavırlar içerisinde olmasını sağlamaktadır. (Dilmaç, 2007).

\section{Akran İlişkilerinin Öznel İyi Oluş ve İnsanî Değerler ile İlişkisi}

Yapılan çalışmalar, akran ilişkilerinin öznel iyi oluşu arttırmada ve olumsuz duyguları azaltmada oldukça etkili değişkenler olduğunu göstermektedir (Cüceloğlu, 1992; Dönmezer, 1999). Mutlu olan ve olmayan insanların karşılaştırmalı olarak incelendiği araştırmalarda, mutlu olan bireylerin daha nitelikli arkadaşlıklarının olduğu, sosyal bağlarının daha güçlü olduğu görülmüştür (Diener, Diener ve Tamir, 2004). Buna göre, öğrencilerin arkadaşlar, aile üyeleri ve dostlar gibi hayattaki özel insanlarla doyum verici ilişkiler içinde olmalarının, kendilerini mutlu hissetmelerinin anlamlı bir yordayıcısı olduğu söylenebilir (Duru ve Türkdoğan, 2012).

Arkadaş grupları sadakat, cesaret, dürüstlük, güven, sorumluluk değerlerinin kazanıldığı ortamlardır (Döğücü, 2004). Değerler genetik bir yolla aktarılmayıp sosyal ortam ve rollerle öğrenilerek gelecek nesillere aktarılır. Sürdürülen ve yaşatılan değerlerin hem aile hem akran gruplarınca kabul görmesi, onaylanması ve desteklenmesi bu değerleri kalıcı hale getirir (Sarı, 2005).

Yapılan alanyazın taraması sonucunda sayıları artan imam hatip lisesi ve imam hatip ortaokullarına karşın örneklem grubu bu okullar olan araştırma sayısının oldukça az sayıda olduğu, akran ilişkileri, öznel iyi oluş ve insanî değerler değişkenleri imam hatip liselerinde ele alan araştırmalar olsa da üç değişkeni aynı anda ele alan çalışmaya rastlanmadığı tespit edilmiştir. Buradan yola çıkarak, bu araştırmada "İmam Hatip Lisesi Öğrencilerinin Akran İlişkilerinin, İnsanî Değerler ve Öznel İyi Oluşları Açısından İncelenmesi” amaçlanmıştır. $\mathrm{Bu}$ bağlamda araştırmanın değişkenleri, birbiri ile ilişkilerinin yanı sıra cinsiyet, sınıf düzeyi, anne ve babanın eğitim düzeylerine göre farklılaşıp farklılaşmadığının da incelenmesi amaçlanmıştır. 


\section{Yöntem}

\section{Araștırma Modeli}

Araştırma, genel tarama modellerinden ilişkisel tarama modelinde desenlenmiştir. Bu kapsamda elde edilen veriler nicel teknikler kullanılarak analiz edilmiştir. Tarama modeli içinde bulunulan anda ya da geçmişte olan bir durumu var olduğu hâli ile betimlemeyi ve tanımlamayı, objektif bir şekilde gözlemlemeyi ve betimlemeyi amaç edinen bir yaklaşımdır (Karasar, 2015).

\section{Evren ve Örneklem}

$\mathrm{Bu}$ araştırmanın evreni, 2014-2015 eğitim-öğretim y1lında İstanbul ilindeki Anadolu imam hatip liselerinde öğrenim gören öğrencilerden oluşmaktadır. Araştırmanın örnekleminde küme örnekleme yöntemi ile seçilen, Anadolu ve Avrupa yakasinda yer alan 5 Anadolu imam hatip lisesi ve her lisenin 9., 10., 11. ve 12. sinıf düzeyinden seçilmiş 543'ü (\%64.8) kız; 295'i (\%35.2) erkek olmak üzere 838 öğrenciyi yer almaktadır.

\section{Veri Toplama Araçları}

Verilerin toplanmasında Öznel İyi Oluş Ölçeği (ÖİOÖ), İnsanî Değerler Ölçeği (İDÖ), Akran İlişkileri Ölçeği (AİÖ) ve Kişisel Bilgi Formu kullanılmıştır.

Kişisel Bilgi Formu: Araştırmacı tarafından hazırlanan Kişisel Bilgi Formu'nda örneklem grubunun sınıf düzeyi, cinsiyet, anne-baba mesleği, anne-baba eğitim durumu, anne-baba birlikteliği vs. belirlemeye yönelik sorular yer almaktadir.

Akran İlişsileri Ölçeği (AİÖ): Akran İlişkileri Ölçeği, Kaner (2000) tarafindan Sosyal Kontrol ve Sosyal Öğrenme Kuramlarına dayalı olarak 14-18 yaş grubundaki ergenlerin akran ilişkilerini incelemek amacıyla geliştirilmiştir. Ölçek, dörtlü likert tipinde hazırlanan 18 madde ve "Bağl1lık, Güven ve Özdeşim, Kendini Açma, Sadakat" olmak üzere 4 alt boyuttan oluşmaktadır. Ölçeğin Cronbach Alfa iç tutarlılık katsayısı bağlılık alt ölçeği için .86, güven ve özdeşim alt ölçeği için .69, kendini açma alt ölçeği için .58, Sadakat alt ölçeği için .58 ve ölçeğin tamamına ilişkin .86 olarak hesaplanmıştır. Ölçeğin test tekrar test güvenirlik katsayıları ise bağlllık alt ölçeği için .93, güven ve özdeşim alt ölçeği için .88, kendini açma alt ölçeği için .84 , sada- 
kat alt ölçeği için .77 ve ölçeğin tamamına ilişkin .93 bulunmuştur. Ölçeğin iki yarım güvenirlik katsayıları ise .60 ile .84 arasında değişmektedir.

Öznel İyi Oluş Ölçeği (ÖIOÖ): Özen (2005) tarafından geliştirilen Öznel İyi Oluş Ölçeği, kişinin hayat doyumunu etkileyen alanlara ilişkin kişisel yarg1lar ile olumlu ve olumsuz duygu ifadelerinden oluşan 37 maddelik bir ölçektir. Ölçeğin güvenirlik analizlerinde Cronbach Alfa güvenirlik katsayısı .91; test-tekrar-test uygulaması sonucu hesaplanan Pearson Momentler Çarpım Korelasyon Katsayıs1 .82 olarak bulunmuştur. Ölçüt geçerliğinde Oskay (1988) tarafindan Türkçeye uyarlanan "Reynolds Ergen Depresyon Ölçeği”" kullanılmıştır. Spearman'ın rho katsayısı sonuçlarına göre puanlar arasında -.60 değerinde negatif ve anlamlı bir ilişki bulunmuştur (akt; Özen, 2005).

İnsanî Değerler Ölçeği (IDÖ): İnsanî Değerler Ölçeği Dilmaç (2007) tarafından ortaöğrenim düzeyindeki öğrenciler için geliştirilmiştir. Beşli likert tipinde hazırlanan ölçek, 42 maddeden oluşmaktadır. Ölçeğin "Sorumluluk", "Dostluk/Arkadaşlık", "Barışçı Olma", "Saygı", "Hoşgörü”, ve "Dürüstlük" olmak üzere altı boyutu bulunmaktadır. Faktörler ve ölçek bütünü için alfa iç tutarlılık katsayıları sırası ile $.73, .69, .65, .67, .69, .70$ ve. 92 olarak hesaplanmıştır.

\section{Verilerin Toplanması}

İstanbul Valiliği İl Millî Eğitim Müdürlüğü’nden uygulama izni al1narak, ölçeklerin uygulamaları araştırmacı tarafından sınıf ortamında yapılmıştır ve her grupta yaklaşık olarak 35-40 dakika sürmüştür.

\section{Verilerin Çözümlenmesi ve Yorumlanması}

Veri toplama işleminin ardından, ölçeklerin puanlama işlemine geçilmiş, eksik, hatalı ve özensiz doldurulan ölçekler puanlama işlemine dâhil edilmemiştir. Veriler SPSS 15.0 istatistik paket programı kullanılarak analiz edilmiştir. Grubun genel yapısını tanıtıcı frekans ve yüzde dağılımları, ölçme aracından alınan puanların ortalama $(\bar{x})$ ve standart sapma (ss) değerleri hesaplanmıştır. Araştırmanın değişkenleri arasındaki ilişkiler Pearson Momentler Çarpım Korelasyon Katsayısı tekniğiyle, demografik değişkenlerin etkisinin sınanması ise kategori sayılarına göre Bağımsız Gruplar t Testi, Mann Whitney-U Testi, Tek Yönlü Varyans Analizi (ANOVA) ve Kruskal Wallis-H analizleri ile gerçekleştirilmiştir. 


\section{Bulgular}

Bu bölümde araştırmanın amacı olan akran ilişkilerinin, öznel iyi oluş ve insanî değerlerin birbirleriyle ilişkisi ve akran ilişkileri, öznel iyi oluş ve insanî değerlerin demografik değişkenlere göre anlamlı farkl1lık gösterip göstermediğine ilişkin bulgulara yer verilmiştir.

Tablo 1. Akran İlişkileri Ölçeği, Öznel İyi Oluş Ölçeği ve İnsanî Değerler Ölçeği Puanları Arasındaki İlişkiyi Belirlemek Üzere Yapılan Pearson Momentler Çarpımı Korelasyon Katsayısı Analizi Sonuçları

\begin{tabular}{|c|c|c|c|c|c|c|c|c|}
\hline \multirow{2}{*}{$\begin{array}{c}\text { Akran } \\
\text { İlişkileri } \\
\text { Alt } \\
\text { Boyutları }\end{array}$} & \multirow[b]{2}{*}{$\begin{array}{c}\text { Öznel } \\
\text { İyi Oluş }\end{array}$} & \multicolumn{7}{|c|}{ İnsanî Değerler Ölçeği Alt Boyutları } \\
\hline & & $\begin{array}{c}\text { Sorum- } \\
\text { luluk }\end{array}$ & $\begin{array}{c}\text { Dostluk/ } \\
\text { Arkadaş- } \\
1 \mathrm{lk} \\
\end{array}$ & $\begin{array}{c}\text { Barış̧ı } \\
\text { Olma }\end{array}$ & Sayg1 & $\begin{array}{c}\text { Dürüst- } \\
\text { lük }\end{array}$ & Hoşgörü & $\begin{array}{c}\text { İnsanî } \\
\text { Değerleı } \\
\text { Toplam } \\
\end{array}$ \\
\hline Bağl1lık & $.410^{* * * *}$ & $.182^{* * *}$ & $.436^{* * *}$ & $.126^{* * * *}$ & $.154^{* * * *}$ & $.144^{* * *}$ & .001 & $.285^{* * * *}$ \\
\hline $\begin{array}{l}\text { Güven ve } \\
\text { Özdeşim }\end{array}$ & $.202^{* * *}$ & .072 & $.460 * * *$ & $.103^{* * *}$ & .091 & .043 & .000 & $.212^{* * *}$ \\
\hline $\begin{array}{l}\text { Kendini } \\
\text { Açma }\end{array}$ & -.008 & .003 & $.439^{* * *}$ & .047 & .019 & -.016 & -.013 & $.133^{* * *}$ \\
\hline Sadakat & $-.200 * * *$ & -.210 **** & $.161 * * *$ & $-.251^{* * * *}$ & -.200 **** & $-.288 * * * *$ & .032 & $-.203^{* * * *}$ \\
\hline $\begin{array}{l}\text { Akran } \\
\text { İlisskileri } \\
\text { Toplam }\end{array}$ & $.208^{* * *}$ & .055 & $.537 * * *$ & .038 & .054 & .000 & .005 & $.191 * * *$ \\
\hline
\end{tabular}

Tablo 1'de görüldüğü gibi öğrencilerin akran ilişkileri "Bağl1lık" alt boyutu ile öznel iyi oluş arasında ( $\mathrm{r}=.410, p<.001)$, insanî değerler "Sorumluluk" alt boyutu arasında $(\mathrm{r}=.182, p<.001)$, insanî değerler "Dostluk/Arkadaşlık" alt boyutu arasında $(\mathrm{r}=.436, p<.001)$, insanî değerler "Barışçı Olma" alt boyutu arasında ( $\mathrm{r}=.126, p<.001)$, insanî değerler "Saygı" alt boyutu arasında $(\mathrm{r}=.154, p<.001)$, insanî değerler "Dürüstlük" alt boyutu arasında $(\mathrm{r}=.144, p<.001)$, insanî değerler toplam puan arasında $(\mathrm{r}=.285$, $p<.001)$ pozitif yönde anlamlı bir ilişki bulunmuştur.

Akran ilişkileri "Güven ve Özdeşim" alt boyutu ile öznel iyi oluş arasinda $(\mathrm{r}=.202, p<.001)$, insanî değerler "Dostluk/Arkadaşl1k" alt boyutu arasında $(\mathrm{r}=.460, p<.001)$, insanî değerler toplam puan arasında $(\mathrm{r}=.212$, $p<.001)$ pozitif yönde anlamlı bir ilişki bulunmuştur. Akran ilişkileri "Kendini Açma" alt boyutu ile insanî değerler "Dostluk/Arkadaşlık" alt boyutu arasında $(\mathrm{r}=.439, p<.001)$ pozitif yönde anlamlı bir ilişki bulunmuştur. 
Akran ilişkileri "Sadakat" alt boyutu ile öznel iyi oluş arasında ( $\mathrm{r}=-.200, p<.001)$, insanî değerler "Barışçı Olma" alt boyutu arasında $(\mathrm{r}=-.251, p<.001)$, insanî değerler "Saygı" alt boyutu arasında $(\mathrm{r}=-.200$, $p<.001)$, insanî değerler "Dürüstlük" alt boyutu arasında $(\mathrm{r}=-.288, p<.001)$, insanî değerler toplam puan arasında $(\mathrm{r}=-.203, p<.001)$ negatif yönde, insanî değerler "Dostluk/Arkadaşl1k" alt boyutu arasında $(\mathrm{r}=.161, p<.001)$ pozitif yönde anlamlı bir ilişki bulunmuştur. Akran ilişkileri toplam puan ile öznel iyi oluş arasında ( $\mathrm{r}=.208, p<.001)$, insanî değerler "Dostluk/Arkadaşlık" alt boyutu arasında $(\mathrm{r}=.537, p<.001)$, insanî değerler toplam puan arasında $(\mathrm{r}=.191, p<.001)$ pozitif yönde anlamlı bir ilişki bulunmuştur.

Tablo 2. Akran İlişkileri Ölçeği ve Alt Boyutlarının Cinsiyet Değişkenine Göre Farklılaşıp Farklılaşmadığını Belirlemek Üzere Yapılan Bağımsız Grup $\mathrm{t}$ Testi Sonuçları

\begin{tabular}{|c|c|c|c|c|c|c|c|}
\hline \multirow{2}{*}{ Puan } & \multirow{2}{*}{ Gruplar } & \multirow{2}{*}{$N$} & \multirow{2}{*}{$\overline{\mathrm{X}}$} & \multirow{2}{*}{ ss } & \multicolumn{3}{|c|}{$t$ Testi } \\
\hline & & & & & $t$ & $S d$ & $p$ \\
\hline \multirow{2}{*}{ Bağlllık } & Kiz & 543 & 34.04 & 5.11 & \multirow{2}{*}{5.068} & \multirow{2}{*}{836} & \multirow{2}{*}{.000} \\
\hline & Erkek & 295 & 32.08 & 5.79 & & & \\
\hline \multirow{2}{*}{$\begin{array}{l}\text { Güven ve } \\
\text { Özdeşim }\end{array}$} & Kiz & 543 & 15.06 & 3.22 & \multirow{2}{*}{.804} & \multirow{2}{*}{836} & \multirow{2}{*}{.421} \\
\hline & Erkek & 295 & 14.87 & 3.24 & & & \\
\hline \multirow{2}{*}{ Kendini Açma } & Kiz & 543 & 9.41 & 3.26 & \multirow{2}{*}{8.039} & \multirow{2}{*}{836} & \multirow{2}{*}{.000} \\
\hline & Erkek & 295 & 7.53 & 3.20 & & & \\
\hline \multirow{2}{*}{ Sadakat } & Kiz & 543 & 6.62 & 2.82 & \multirow{2}{*}{-5.248} & \multirow{2}{*}{836} & \multirow{2}{*}{.000} \\
\hline & Erkek & 295 & 7.76 & 3.25 & & & \\
\hline Akran İlişkileri & Kız & 543 & 65.14 & 10.39 & \multirow{2}{*}{3.727} & \multirow{2}{*}{836} & \multirow{2}{*}{.000} \\
\hline Toplam & Erkek & 295 & 62.24 & 11.39 & & & \\
\hline
\end{tabular}

Tablo 2'de görüldüğü üzere bağl1lık alt boyutunda grupların aritmetik ortalamaları arasındaki fark istatistiksel açıdan anlamlı bulunmuştur $(\mathrm{t}=5.068, p<.001)$. Söz konusu farklı1ık kız öğrencilerin lehinedir. Yani kız öğrencilerin bağl11ı puanları erkek öğrencilerin bağl11ı puanlarından anlamlı şekilde yüksek bulunmuştur. Cinsiyet değişkenine göre kendini açma alt boyutunda k1zlar lehine $(\mathrm{t}=8.039, p<.001)$, sadakat alt boyutunda erkek öğrenciler lehine $(\mathrm{t}=-5.248, p<.001)$ ve akran ilişkileri toplam puanlarında da kızlar lehine ( $\mathrm{t}=3.727, p<.001)$ anlamlı farklılıklar elde edilmiştir. 
Tablo 3. Öznel İyi Oluş Puanlarının Cinsiyet Değişkenine Göre Farklılaşıp Farklılaşmadığını Belirlemek Üzere Yapılan Bağımsız Grup t Testi Sonuçlar1

\begin{tabular}{llcccccc}
\hline \multirow{2}{*}{ Puan } & \multirow{2}{*}{ Gruplar } & \multirow{2}{*}{$N$} & \multirow{2}{*}{} & \multirow{2}{*}{$\boldsymbol{s}$} & & \multicolumn{3}{c}{$t$ Testi } \\
\cline { 6 - 8 } & & & & & $\boldsymbol{t}$ & $S d$ & $p$ \\
\hline Öznel İyi & Kız & 543 & 134.26 & 21.20 & & \multirow{2}{*}{ Olus } \\
Oluş & Erkek & 295 & 135.05 & 20.78 & & 836 & .603 \\
\hline
\end{tabular}

Bağımsız Gruplar t Testi sonucuna göre, grupların aritmetik ortalamaları arasındaki fark istatistiksel açıdan anlamlı bulunmamıştır ( $\mathrm{t}=-.521$, $p>.05)$.

Tablo 4. İnsanî Değerler Ölçeği ve Alt Boyutlarının Cinsiyet Değişkenine Göre Farklılaşıp Farklılaşmadığını Belirlemek Üzere Yapılan Bağımsız Grup t Testi Sonuçları

\begin{tabular}{|c|c|c|c|c|c|c|c|}
\hline \multirow{2}{*}{ Puan } & \multirow{2}{*}{ Gruplar } & \multirow{2}{*}{$N$} & \multirow{2}{*}{$\overline{\mathrm{X}}$} & \multirow{2}{*}{$S S$} & \multicolumn{3}{|c|}{$t$ Testi } \\
\hline & & & & & $t$ & $S d$ & $p$ \\
\hline \multirow{2}{*}{ Sorumluluk } & Kiz & 543 & 24.84 & 4,82 & \multirow{2}{*}{-.147} & \multirow{2}{*}{836} & \multirow{2}{*}{.883} \\
\hline & Erkek & 295 & 24.89 & 4.40 & & & \\
\hline \multirow{2}{*}{$\begin{array}{l}\text { Dostluk/ } \\
\text { Arkadaşlık }\end{array}$} & $\mathrm{K} 1 \mathrm{z}$ & 543 & 27.86 & 4.35 & \multirow{2}{*}{3.881} & \multirow{2}{*}{836} & \multirow{2}{*}{.000} \\
\hline & Erkek & 295 & 26.62 & 4.49 & & & \\
\hline \multirow{2}{*}{$\begin{array}{l}\text { Barışçı } \\
\text { Olma }\end{array}$} & Kız & 543 & 26.89 & 4.366 & \multirow{2}{*}{5.780} & \multirow{2}{*}{836} & \multirow{2}{*}{.000} \\
\hline & Erkek & 295 & 25.08 & 4.212 & & & \\
\hline \multirow{2}{*}{ Sayg1 } & $\mathrm{K} 1 \mathrm{Z}$ & 543 & 26.27 & 4.645 & \multirow{2}{*}{-.824} & \multirow{2}{*}{836} & \multirow{2}{*}{.410} \\
\hline & Erkek & 295 & 26.54 & 4.393 & & & \\
\hline \multirow{2}{*}{ Dürüstlük } & $\mathrm{K} 1 \mathrm{z}$ & 543 & 26.64 & 3.591 & \multirow{2}{*}{5.460} & \multirow{2}{*}{836} & \multirow{2}{*}{.000} \\
\hline & Erkek & 295 & 25.17 & 3.926 & & & \\
\hline \multirow{2}{*}{ Hoşgörü } & $\mathrm{K} 1 \mathrm{z}$ & 543 & 23.20 & 3.510 & \multirow{2}{*}{1.863} & \multirow{2}{*}{836} & \multirow{2}{*}{.063} \\
\hline & Erkek & 295 & 22.73 & 3.376 & & & \\
\hline İ̀nsanî & $\mathrm{K} 1 \mathrm{z}$ & 543 & 155.70 & 16.02 & \multirow{2}{*}{4.036} & \multirow{2}{*}{836} & \multirow{2}{*}{.000} \\
\hline Değerler Toplam & Erkek & 295 & 151.05 & 15.74 & & & \\
\hline
\end{tabular}

Tablo 4'te görüldüğü üzere, Dostluk/arkadaşl1k ( $\mathrm{t}=3.881, p<.001)$, Barışç1 olma ( $\mathrm{t}=5.780, p<.001)$, Dürüstlük $(\mathrm{t}=4.036, p<.001)$ ve İnsanî değerler toplam puanlarında $(\mathrm{t}=4.036, p<.001)$ kızlar lehine istatistiksel açıdan anlamlı farklılıklar elde edilmiştir. 
Tablo 5. Güven ve Özdeşim Puanlarının Sınıf Düzeyine Göre Farklılaşıp Farklılaşmadığını Belirlemek Üzere Yapılan Tek Yönlü Varyans Analizi (ANOVA) Sonuçları

$f, \overline{\mathrm{X}}$ ve $s s$ Değerleri

\begin{tabular}{llccccccccc}
\hline Puan & Grup & $N$ & $\overline{\mathrm{X}}$ & $\boldsymbol{S S}$ & Var. K. & $K T$ & $S d$ & $K O$ & $F$ & $p$ \\
\hline \multirow{3}{*}{ Güven } & 9.Sınıf & 214 & 15.39 & 3.060 & G.Arası & 85.891 & 3 & 28.630 & 2.769 & .041 \\
ve & 10.Sınıf & 249 & 14.81 & 3.128 & G.İçi & 8624.066 & 834 & 10.341 & & \\
Özdeşim & 11.Sınıf & 203 & 14.59 & 3.363 & Toplam & 8709.957 & 837 & & & \\
& 12.Sınıf & 172 & 15.24 & 3.348 & & & & & & \\
& Toplam & 838 & 14.99 & 3.226 & & & & & & \\
\hline
\end{tabular}

Tablo 5'te görüldüğü grupların aritmetik ortalamaları arasındaki farkl111k anlamlı bulunmuştur $(\mathrm{F}=2.769, p<.05)$. Post-hoc sonucuna göre bu farklılık, 9. sınıf öğrencileri ile 11. sınıf öğrencileri arasında, 9. sınıf öğrencileri lehine gerçekleşmiştir. Akran ilişkileri "Bağlllık, Sadakat" alt boyutu ile akran ilişkileri toplam puanlarında ve öznel iyi oluş puanlarında sınıf düzeyine göre farklılıklar oluşmamıştır.

Sınıf düzeyi İnsanî Değerler Ölçeği'nde ise Sorumluluk, Dostluk/Arkadaşlık, Barışçı Olma, Saygı, Hoşgörü alt boyutu ve insanî değerler toplam puanlarında anlamlı bir farklılık oluşturmamıştır ( $p>.05)$.

Tablo 6. Kendini Açma Puanlarının Sınıf Düzeyi Değişkenine Göre Farklılaşıp Farklılaşmadığını Belirlemek Üzere Yapılan Tek Yönlü Varyans Analizi (ANOVA) Sonuçları

\begin{tabular}{llccccccccc}
\hline & $f, \overline{\mathrm{X}}$ ve & $\boldsymbol{S} S$ Değerleri & \multicolumn{6}{c}{ ANOVA Sonuçları } \\
\hline Puan & Grup & $N$ & $\overline{\mathrm{X}}$ & $\boldsymbol{S S}$ & Var. K. & $K T$ & $S d$ & $K O$ & $F$ & $p$ \\
\hline \multirow{4}{*}{ Kendini } & 9.Sınıf & 214 & 8.60 & 3.339 & G.Arasi & 140.644 & 3 & 46.881 & 4.206 & .006 \\
Açma & 10.Sınıf & 249 & 8.28 & 3.213 & G.İçi & 9295.728 & 834 & 11.146 & & \\
& 11.Sınıf & 203 & 8.94 & 3.466 & Toplam & 9436.372 & 837 & & & \\
& 12.Sınıf & 172 & 9.40 & 3.362 & & & & & & \\
& Toplam & 838 & 8.75 & 3.358 & & & & & & \\
\hline
\end{tabular}

ANOVA sonucuna göre sınıf düzeyi kendini açma puanlarında farkl1l1k oluşturmuştur $(\mathrm{F}=4.206, p<.01)$. Bu farkl11ık, 9. sınıf öğrencileri ile 12. sinıf öğrencileri arasında, 12. sınıf öğrencileri lehine; 10. sinıf öğrencileri ile 11. ve 12. sınıf öğrencileri arasında, 10. sınıf öğrencileri aleyhine oluşmuştur. 
Tablo 7. Dürüstlük Puanlarının Sınıf Düzeyi Değişkenine Göre Farklılaşıp Farklılaşmadığını Belirlemek Üzere Yapılan Tek Yönlü Varyans Analizi (ANOVA) Sonuçları

$f, \overline{\mathrm{x}}$ ve $s s$ Değerleri

ANOVA Sonuçları

\begin{tabular}{llccccccccc}
\hline Puan & Grup & $N$ & $\overline{\mathrm{x}}$ & $S S$ & Var. K. & $K T$ & $S d$ & $K O$ & $F$ & $p$ \\
\hline \multirow{4}{*}{ Dürüst- } & 9.Sinıf & 214 & 25.43 & 4.035 & G.Arası & 142.900 & 3 & 47.633 & 3.370 & .018 \\
lük & 11.Sinıf & 249 & 26.33 & 3.755 & G.İ̧i & 11789.440 & 834 & 14.136 & & \\
& 12.Sinıf & 203 & 26.28 & 3.608 & Toplam & 11932.340 & 837 & & & \\
& Toplam & 838 & 26.50 & 3.583 & & & & & & \\
\hline
\end{tabular}

Tablo 7'de görüldüğü üzere Dürüstlük alt boyutundaki farklılıklar istatistiksel olarak anlamlı bulunmuştur $(\mathrm{F}=3.370, p<.05)$. Bu farklılık, 9. sınıf öğrencileri ile 10., 11. ve 12. sınıf öğrencileri arasında 10. sınıf öğrencileri aleyhine oluşmuştur.

Akran ilişkileri Bağl1lık, Güven ve Özdeşim, Kendini Açma alt boyutları ve akran ilişkileri toplam puanlarında ayrıca öznel iyi oluş puanlarında farklılıklar elde edilmemiştir.

İnsanî Değerler Ölçeği'nin de Dostluk/Arkadaşlık, Sayg1, Dürüstlük, Hoşgörü alt boyutlarında anne eğitim durumuna göre anlamlı bir farklılık elde edilmemiştir.

Tablo 8. Sadakat Puanlarının Anne Eğitim Durumu Değişkenine Göre Farklılaşıp Farklılaşmadığını Belirlemek Üzere Yapılan Tek Yönlü Varyans Analizi (ANOVA) Sonuçları

\begin{tabular}{llccccccccc}
\hline \multicolumn{4}{l}{$f, \overline{\mathrm{X}}$ ve } & $\boldsymbol{S} \boldsymbol{S}$ Değerleri & \multicolumn{6}{c}{ ANOVA Sonuçları } \\
\hline Puan & Grup & $N$ & $\overline{\mathrm{X}}$ & $\boldsymbol{S S}$ & Var. K. & $K T$ & $S d$ & $K O$ & $F$ & $p$ \\
\hline & İlkokul & 396 & 6.72 & 2.960 & G.Arası & 73.993 & 3 & 24.664 & 2.706 & .044 \\
& Ortaokul & 173 & 7.24 & 3.115 & G.İçi & 7600.577 & 834 & 9.113 & & \\
Sadakat & Lise & 172 & 7.41 & 2.932 & Toplam & 7674.569 & 837 & & & \\
& Üniversite & & & & & & & & & \\
& ve üstü & 97 & 7.20 & 3.230 & & & & & & \\
& Toplam & 838 & 7.02 & 3.028 & & & & & & \\
\hline
\end{tabular}

Tablo 8'de görüldüğü gibi anne eğitim düzeyine göre sadakat boyutunda farklılıklar oluşmuştur $(\mathrm{F}=2.706, p<.05)$. Söz konusu farklılığın annesi ilkokul mezunu olanlar ile annesi lise mezunu olan öğrenciler arasında, annesi lise mezunu olan öğrenciler lehine gerçekleştiği saptanmıştır. 
Tablo 9. Sorumluluk Puanlarının Anne Eğitim Durumu Değişkenine Göre Farklılaşıp Farklılaşmadığını Belirlemek Üzere Yapılan Tek Yönlü Varyans Analizi (ANOVA) Sonuçları

\begin{tabular}{|c|c|c|c|c|c|c|c|c|c|c|}
\hline & $f, \overline{\mathrm{x}}$ ve & $S S \quad \mathrm{D}$ & ğerleri & & & ANO & VA S & onuçları & & \\
\hline Puan & Grup & $N$ & $\overline{\mathrm{X}}$ & $S S$ & Var. K. & $K T$ & $S d$ & KO & $F$ & $p$ \\
\hline \multirow{5}{*}{$\begin{array}{l}\text { Sorum- } \\
\text { luluk }\end{array}$} & İlkokul & 396 & 25.29 & 4.654 & G.Arası & 300.739 & 3 & 100.246 & \multirow[t]{5}{*}{4.641} & \multirow[t]{5}{*}{.003} \\
\hline & Ortaokul & 173 & 24.36 & 4.827 & G.İçi & 18014.645 & 834 & 21.600 & & \\
\hline & Lise & 172 & 25.13 & 4.576 & Toplam & 18315.384 & 837 & & & \\
\hline & $\begin{array}{l}\text { Üniversite } \\
\text { ve üstü }\end{array}$ & 97 & 23.53 & 4.416 & & & & & & \\
\hline & Toplam & 838 & 24.86 & 4.678 & & & & & & \\
\hline
\end{tabular}

Analiz sonuçlarına göre anne eğitimi sorumluluk puanlarında farkl1lıklar oluşturmuştur $(\mathrm{F}=.641, p<.01)$. Bu farklılığın annesi ilkokul mezunu olan öğrenciler ile annesi ortaokul, üniversite ve üstü mezunu olan öğrenciler arasında annesi ilkokul mezunu olan öğrenciler lehine oluştuğu saptanmıştır. Ayrıca annesi lise mezunu olan öğrenciler ile annesi üniversite ve üstü mezunu olan öğrenciler arasında annesi lise mezunu olan öğrenciler lehine farklilıklar elde edilmiştir.

Tablo 10. Barışçı Olma Puanlarının Anne Eğitim Durumu Değişkenine Göre Farklılaşıp Farklılaşmadığını Belirlemek Üzere Yapılan Tek Yönlü Varyans Analizi (ANOVA) Sonuçları

\begin{tabular}{llccccccccc}
\hline & $f, \overline{\mathrm{X}}$ ve & $S S$ & Değerleri & \multicolumn{6}{c}{ ANOVA Sonuçları } \\
\hline Puan & Grup & $N$ & $\overline{\mathrm{X}}$ & $\boldsymbol{S S}$ & Var. K. & $K T$ & $S d$ & $K O$ & $F$ & $p$ \\
\hline \multirow{3}{*}{ Barışçı } & İlkokul & 396 & 26.172 & 4.193 & G.Arası & 171.292 & 3 & 57.097 & 2.977 & .031 \\
Olma & Ortaokul & 173 & 25.77 & 4.727 & G.İçi & 15997.075 & 834 & 19.181 & & \\
& Üniversite & 172 & 25.99 & 4.178 & Toplam & 16168.368 & 837 & & & \\
& ve üstü & 97 & 25.67 & 4.815 & & & & & & \\
& Toplam & 838 & 26.25 & 4.395 & & & & & & \\
\hline
\end{tabular}

Tablo 10'da görüldüğü üzere barışçı olma puanlarında anne eğitim düzeyi farklılık oluşturmuştur. $\mathrm{Bu}$ farklılığın annesi ilkokul mezunu olan öğrenciler ile annesi ortaokul, üniversite ve üstü mezunu olan öğrenciler arasında annesi ilkokul mezunu olan öğrenciler lehine gerçekleştiği saptanmıştır. 
Tablo 11. İnsanî Değerler Toplam Puanlarının Anne Eğitim Durumu Değişkenine Göre Farklılaşıp Farklılaşmadığını Belirlemek Üzere Yapılan Tek Yönlü Varyans Analizi (ANOVA) Sonuçları

$f, \overline{\mathrm{X}}$ ve $s s$ Değerleri ANOVA Sonuçları

\begin{tabular}{|c|c|c|c|c|c|c|c|c|c|c|}
\hline Puan & Grup & $N$ & $\overline{\mathrm{X}}$ & SS & Var. K. & $K T$ & $S d$ & $K O$ & $F$ & $p$ \\
\hline \multirow{5}{*}{$\begin{array}{l}\text { İnsanî } \\
\text { Değerler }\end{array}$} & İlkokul & 396 & 155.26 & 15.811 & G.Arası & 3208.678 & 3 & 1069.559 & 4.190 & .006 \\
\hline & Ortaokul & 173 & 153.24 & 14.660 & G.İçi & 212882.338 & 834 & 255.255 & & \\
\hline & Lise & 172 & 154.93 & 16.941 & Toplam & 216091.017 & 837 & & & \\
\hline & $\begin{array}{l}\text { Üniversite } \\
\text { ve üstü }\end{array}$ & 97 & 149.09 & 15.462 & & & & & & \\
\hline & Toplam & 838 & 154.06 & 16.068 & & & & & & \\
\hline
\end{tabular}

Tablo 11'de görüldüğü üzere insanî değerler puanlarında da anne eğitim düzeyine göre farkl1lıklar elde edilmiştir. Söz konusu farklılıklar annesi üniversite ve üstü mezunu olan öğrenciler ile annesi ilkokul, ortaokul mezunu ve lise mezunu olan öğrenciler arasında gerçekleştiği saptanmıştır. $\mathrm{Bu}$ farklılık annesi üniversite ve üstü mezunu olan öğrenciler aleyhinedir.

Akran ilişkilerinde Bağlılık, Güven ve Özdeşim, Kendini Açma alt boyutları ve toplam puanın yanı sıra öznel iyi oluş puanlarında farklılık oluşturmamıştır.

İnsanî Değerler Ölçeği'nde de Dostluk/Arkadaşlık, Saygı, Dürüstlük, Hoşgörü alt boyutlarında baba eğitim durumu değişkenine göre anlamlı bir farklı1ık bulunmamıştır.

Tablo 12. Sadakat Puanlarının Baba Eğitim Durumu Değişkenine Göre Farklılaşıp Farklılaşmadığını Belirlemek Üzere Yapılan Tek Yönlü Varyans Analizi (ANOVA) Sonuçları

\begin{tabular}{llccccccccc}
\hline & $f, \overline{\mathrm{X}}$ ve & $S S$ Değerleri & \multicolumn{6}{c}{ ANOVA Sonuçları } \\
\hline Puan & Grup & $N$ & $\overline{\mathrm{X}}$ & $\boldsymbol{S S}$ & Var. K. & $K T$ & $S d$ & $K O$ & $F$ & $p$ \\
\hline \multirow{6}{*}{ Sadakat } & İlkokul & 209 & 6.59 & 2.992 & G.Arası & 75.673 & 3 & 25.224 & 2.768 & .041 \\
& Ortaokul & 179 & 6.89 & 3.033 & G.İçi & 7598.896 & 834 & 9.111 & & \\
& Lise & 207 & 718 & 3.075 & Toplam & 7674.569 & 837 & & & \\
& Üniversite & & & & & & & & & \\
& ve üstü & 243 & 7.36 & 2.981 & & & & & & \\
& Toplam & 838 & 7.02 & 3.028 & & & & & & \\
\hline
\end{tabular}

Tablo 12'de görüldügü üzere baba eğitim düzeyi, sadakat puanlarının anlamlı farklılık oluşturmuştur $(\mathrm{F}=2.768, p<.05)$. Bu farklılığın, babası il- 
kokul mezunu olan öğrenciler ile babası lise, üniversite ve üstü mezunu olan öğrenciler arasında, babası ilkokul mezunu olan öğrenciler aleyhine gerçekleştiği saptanmıştır.

Tablo 13. Sorumluluk Puanlarının Baba Eğitim Durumu Değişkenine Göre Farklılaşıp Farklılaşmadığını Belirlemek Üzere Yapılan Tek Yönlü Varyans Analizi (ANOVA) Sonuçları

\begin{tabular}{llccccccccc}
\hline & $f, \overline{\mathrm{X}}$ ve & $\boldsymbol{S S}$ Değerleri & \multicolumn{6}{c}{ ANOVA Sonuçları } \\
\hline Puan & Grup & $N$ & $\overline{\mathrm{X}}$ & $\boldsymbol{S S}$ & Var. K. & $K T$ & $S d$ & $K O$ & $F$ & $p$ \\
\hline \multirow{3}{*}{ Sorum- } & İlkokul & 209 & 25.26 & 4.701 & G.Arası & 196.138 & 3 & 65.379 & 3.009 & .029 \\
luluk & Lise & 207 & 24.68 & 4.633 & Toplam & 18315.384 & 837 & & & \\
& Üniversite & & & & & & & & & \\
& ve üstü & 243 & 24.23 & 4.745 & & & & & & \\
& Toplam & 838 & 24.86 & 4.678 & & & & & & \\
\hline
\end{tabular}

Tablo 13'de görüldüğü üzere, ANOVA sonucuna göre öğrencilerin sorumluluk puanlarında, baba eğitimine göre farklılıklar elde edilmiştir $(\mathrm{F}=3.009, p<.05)$. Bu farklılığın babası üniversite ve üstü mezunu olan öğrenciler ile ilkokul ve ortaokul mezunu olan öğrenciler arasında, babası üniversite ve üstü mezunu olan öğrenciler aleyhine gerçekleştiği saptanmıştır.

Tablo 14. Saygı Puanlarının Baba Eğitim Durumu Değişkenine Göre Farklılaşıp Farklılaşmadığını Belirlemek Üzere Yapılan Tek Yönlü Varyans Analizi (ANOVA) Sonuçları

\begin{tabular}{llccccccccc}
\hline & $f, \overline{\mathrm{X}}$ ve & $s \boldsymbol{c}$ Değerleri & \multicolumn{6}{c}{ ANOVA Sonuçları } \\
\hline Puan & Grup & $N$ & $\overline{\mathrm{X}}$ & $\boldsymbol{S S}$ & Var. K. & $K T$ & $S d$ & $K O$ & $F$ & $p$ \\
\hline \multirow{4}{*}{ Saygı } & İlkokul & 209 & 26.71 & 4.808 & G.Arası & 238.148 & 3 & 79.383 & 3.862 & .009 \\
& Ortaokul & 179 & 26.77 & 4.181 & G.İçi & 17142.383 & 834 & 20.554 & & \\
& Lise & 207 & 26.64 & 4.645 & Toplam & 17380.531 & 837 & & & \\
& Üniversite & & & & & & & & & \\
& ve üstü & 243 & 25.53 & 4.443 & & & & & & \\
& Toplam & 838 & 26.37 & 4.557 & & & & & & \\
\hline
\end{tabular}

Tablo 14'te görüldüğü üzere öğrencilerin sayg1 puanların arasındaki farklı1ık anlamlı bulunmuştur $(\mathrm{F}=3.862, p<.05)$. Bu farklılığın babası üniversite ve üstü mezunu olan öğrenciler ile babası ilkokul, ortaokul ve lise mezunu olan öğrenciler arasında, babası üniversite ve üstü mezunu olan öğrenciler aleyhine gerçekleştiği saptanmıştır. 
Tablo 15. İnsanî Değerler Toplam Puanlarının Baba Eğitim Durumu Değişkenine Göre Farklılaşıp Farklılaşmadığını Belirlemek Üzere Yapılan Tek Yönlü Varyans Analizi (ANOVA) Sonuçları

\begin{tabular}{|c|c|c|c|c|c|c|c|c|c|c|}
\hline & $f, \overline{\mathbf{X}}$ ve & $S S$ & eğerleri & & & ANO & A So & ucları & & \\
\hline Puan & Grup & $N$ & $\overline{\mathrm{X}}$ & $S S$ & Var. K. & $K T$ & $S d$ & $K O$ & $F$ & $p$ \\
\hline & İlkokul & 209 & 155.02 & 15.856 & G.Arası & 2291.099 & 3 & 763.700 & 2.979 & .031 \\
\hline & Ortaokul & 179 & 155.45 & 14.705 & G.İci & 213799.918 & 834 & 256.355 & & \\
\hline İnsanî & Lise & 207 & 154.90 & 16.137 & Toplam & 216091.017 & 837 & & & \\
\hline Değerler & Üniversite & & & & & & & & & \\
\hline & ve üstü & 243 & 151.49 & 16.079 & & & & & & \\
\hline & Toplam & 838 & 154.06 & 16.068 & & & & & & \\
\hline
\end{tabular}

Tablo 15'te sunulduğu gibi öğrencilerin insanî değerler toplam puanlarının aritmetik ortalamalarının baba eğitim durumu değişkenine göre anlamlı bir farklılık gösterdiği bulunmuştur $(\mathrm{F}=2.979, p<.05)$. Bu farkl11ığın üniversite ve üstü mezunu olan öğrenciler ile babası ilkokul, ortaokul ve lise mezunu olan öğrenciler arasında, babası üniversite ve üstü mezunu olan öğrenciler aleyhine gerçekleştiği saptanmıştır.

\section{Tartışma ve Sonuç}

Öznel iyi oluş ve akran ilişkileri arasındaki ilişki incelendiğinde, öznel iyi oluş puanları ile "Bağlılık, Güven ve Özdeşim" alt boyutları, akran ilişkileri toplam puan arasında pozitif; "Sadakat" alt boyutu arasında negatif yönde anlamlı bir ilişki olduğu bulunmuştur. İnsanî değerler ve akran ilişkileri arasındaki ilişki incelendiğinde, insanî değerler toplam puanları ve alt boyutlarının akran ilişkileri "Bağlılık" alt boyutu ile arasında pozitif; akran ilişkileri "Sadakat" alt boyutu arasında negatif yönde anlamlı bir ilişki olduğu bulunmuştur.

Alanyazında sosyal zekâsı yüksek ve kişilerarası ilişkilerinde başarılı olan bireylerin mutluluk düzeylerinin yüksek olduğuna yönelik bulgular yer almaktadır. $\mathrm{Bu}$ açıdan değerlendirildiğinde dışadönüklük özelliği yüksek olan bireylerin olumlu duygular yaşamaya eğilimli oldukları ve doyurucu kişilerarası ilişkiler yaşamalarının öznel iyi oluşa olumlu yönde etkide bulunduğu söylenebilir (Lucas ve Fujita, 2000, akt; Ercan ve Ery1lmaz, 2011). Buna göre, öğrencilerin sosyal ilişkilerde gösterdikleri başarının ve arkadaşlar, aile üyeleri ve dostlar gibi hayattaki özel insanlarla doyum verici ilişkiler 
içinde olmalarının, kendilerini mutlu hissetmelerinin anlamlı bir yordayıcısı olduğu söylenebilir (Duru ve Türkdoğan, 2012).

Değerler genellikle, sosyal olarak ebeveynler, öğretmenler, arkadaşlar ve çevredeki diğer bireylerle kurulan iletişimle kazanılmaktadır (Dereli ve Aypay, 2011). Başka bir deyişle değerler genetik bir yolla aktarılmayıp sosyal ortam ve rollerle öğrenilerek gelecek nesillere aktarılır. Sürdürülen ve yaşatılan değerlerin hem aile hem akran gruplarınca kabul görmesi, onaylanması ve desteklenmesi bu değerleri kalıcı hale getirir (Sarı, 2005).

Öğrencilerin akran ilişkileri toplam puan ve "bağl1lık ve kendini açma" alt boyutlarında kız; "sadakat" alt boyutunda ise erkek öğrenciler lehine anlamlı bir farklılık olduğu bulgulanmıştır. Bu bulgulardan hareketle kızların ilişkilerinde duygusal bir yoğunluğun, yakınlığın ve bağlılığın daha belirgin olduğu, kendilerini açma konusunda arkadaşlarına daha fazla güvendiğini, erkeklerin akran ilişkilerinde sağlam ve güçlü bir dostluğun yani sadakatin daha ön planda olduğunu söyleyebiliriz. Aynı zamanda toplumsal cinsiyet rollerinde kızlardan sevgi, duygusallık, paylaşımcı olma; erkeklerden güçlü ve koruyucu olma, sevgisini göstermeme, gözüpek olma gibi özelliklerin beklenmesinin de araştırma bulgularında etkili olduğu görülmektedir. Şimşek (2010)'in YİBO ve ailesi yanında kalan sekizinci sınıf öğrencilerinin akran ilişkilerini incelemek amacıyla yaptığı araştırma sonuçlarında, kız öğrencilerin "bağlılık, kendini açma, sadakat" puanlarının erkek öğrencilerinkinden anlamlı düzeyde yüksek olduğunu bulgulanmıştır. Çömez (2014) fiziksel engelli ergenler ile sağlıklı ergenlerin akran ilişkilerini incelediği araştırmasında akran ilişkileri bağlılık alt boyut puanının kız öğrenciler lehine anlamlı düzeyde farklılaştığı görülmüştür.

Öğrencilerin öznel iyi oluş puanlarının cinsiyet değişkenine göre anlamlı bir farklılık göstermediği bulgusuna ulaşılmıştır. Alanyazında gerçekleştirilen çalışmalarda, bireylerin öznel iyi oluşlarının cinsiyete bağlı olarak anlamlı düzeyde farklılaşmadığı bulunmuştur (Çelik, 2008; Dost, 2005; Saygın, 2009; Şahin, 2011). Wood, Rhodes ve Whelan (1989), iyi oluşla ilgili yapılmış 93 çalışmanın meta analizini yaptıkları çalışmanın sonucunda kadınların erkeklere oranla mutluluk ve yaşam doyumu seviyelerinin daha yüksek olduğunu ancak olumlu duygu durumu açısından bu farklılığın anlamlı olmadığını bulmuşlardır (akt; İşleroğlu, 2012). 
Öğrencilerin insanî değerler "dostluk/arkadaşlık, sayg1 ve dürüstlük" alt boyutları ve toplam puanlarının kız öğrenciler lehine anlamlı bir farklılık gösterdiği tespit edilmiştir. Benzer çalışmalarda Dereli ve Aypay’ın (2011) "dostluk, barışçıl olma, dürüstlük ve saygı" gibi insanî değerlerin kız öğrencilerde daha yüksek bulurken; Erden ve Ümmet (2014) de "güç" ve "uyarılma" değerlerinin erkek öğrencilerde daha yüksek olduğu sonuçlarını elde etmişlerdir. Bu durum toplumsal cinsiyet rolleri ile açıklanabilir. Dökmen (1999) kadınsılık ve erkeksilik rollerine ilişkin ölçek çalışmasında, kadınsı rollerin duygusal, nazik, anlayışlı, hassas, sadık gibi özellikleri; erkeksi rollerin ise lider, otoriter, risk alan, hırslı gibi özellikleri içerdiğini söyler. Bu duruma toplumsal cinsiyet rollerinin ve yetiştirilme farklıl1klarının etki ettiğini söylemek mümkündür.

Akran ilişkileri "güven ve özdeşim" alt boyutu sınıf düzeyi azaldıkça arttığ1; "kendini açma" alt boyutunun ise sınıf düzeyi arttıkça arttığı saptanmıştır. Buna göre liseye yeni başlayan ergenlerin daha güvene dayalı, arkadaşlarını model aldığ 1 bir ilişkiyi önemsedikleri, lisede daha üst sınıflarda bulunan öğrencilerin ise kendilerini rahat bir şekilde açabildikleri, sorunlarını paylaştıkları arkadaşlıklar kurmaya özen gösterdikleri söylenebilir. Alanyazın incelendiğinde ergenlerin akran ilişkileri ile suç kabul edilen davranışları arasındaki ilişkiyi inceleyen Delikara (2000), araştırmasında 17 yaş grubundaki kişilerin ölçeklerden aldıkları puanların ortalamalarının, 14-15-16 yaş puan ortalamalarından anlamlı olarak daha yüksek olduğu bulgulanmıştır.

İnsanî değerler "dürüstlük" alt boyutu sınıf düzeyi arttıkça arttı̆̆ saptanmıştır. Bu bulgu sınıf düzeyi yükseldikçe dürüstlük değerine verilen önemin arttığını göstermektedir. Dereli ve Aypay'ın (2011) ergenlerin insanî değerler düzeylerini incelendiği araştırmasında insanî değerler "barışçıl olma” puanları sınıf düzeyi yükseldikçe anlamlı bir düzeyde yükselmiştir. Bulgulardan hareketle öğrencilerin sınıf düzeylerine göre aldıkları eğitimin sahip oldukları bu gibi özellikleri pekiştireceği, destekleyeceği düşünülmektedir.

Öğrencilerin akran ilişkileri "sadakat" alt boyutunun anne baba eğitim düzeyi arttıkça arttığ tespit edilmiştir. Anne babaların eğitim düzeyi yükseldikçe çocuklarını, akranlarıyla kurduğu bağın daha içten, sağlam ve güçlü olacak şekilde yetiştirmeye özen gösterdikleri söylenebilir. Bu araştırma 
sonucu ile çelişen, ergenlerde akran ilişkileri ve yalnızlık düzeylerinin evde internet kullanımına etkisinin incelendiği bir araştırma sonuçlarına göre akran ilişkilerinin anne baba eğitim durumuna göre farklılaşmadığ 1 tespit edilmiştir (Yücel, 2009).

İnsanî değerler toplam puan ve "sorumluluk, barışçıl olma" alt boyutlarının anne eğitim düzeyi azaldıkça arttığı; insanî değerler toplam puan ve "sorumluluk, saygı" alt boyutları ise baba eğitim düzeyi azaldıkça arttığı tespit edilmiştir. Bu durum, artan eğitim düzeyine bağlı olarak anne ve babaların öncelik verdikleri değerlerin değişmesi, insanî değerlere yükledikleri önemin azalması ve çocuk yetiştirmeye yönelik rekabete dayalı, başarı odak11 tutumlarının baskın hâle gelmesi ile ilişkili olabileceği düşünülmektedir. Dereli ve Aypay (2011) tarafından yapılan, lise öğrenimine devam eden öğrencilerin insanî değerler düzeylerinin incelendiği çalışmada annesi ilköğretim ve lise mezunu olan öğrencilerin "sorumluluk" puan ortalamaları annesi üniversite mezunu olan öğrencilerden daha yüksek; babası lise mezunu olan öğrencilerin "barışçıl olma" puan ortalaması babası üniversite mezunu olan öğrencilerin puanlarından daha yüksek bulunmuştur.

\section{Kaynakça}

Akbaş, O. (2004). Türk milli eğitim sisteminin duyuşsal amaçlarının ilköğretim II. kademede gerçekleşme derecesinin değerlendirilmesi. Yayımlanmamış doktora tezi, Gazi Üniversitesi Eğitim Bilimleri Enstitüsü.

Aypay, A. ve Eryılmaz, A. (2011). Ergen öznel iyi oluşu ile kimlik statüsü ilişkisinin incelenmesi. Dicle Üniversitesi Ziya Gökalp Ĕ̈itim Fakültesi Dergisi, 16, 167-179.

Bacanl1, H. (2002). Psikolojik kavram analizleri. Ankara: Nobel.

Bilgiç, N. (2000). Arkadaşlık becerisi eğitiminin ilköğretim ikinci kademe öğrencilerinin yalnızlı düzeylerine etkisi. Yayımlanmamış yüksek lisans tezi, Gazi Üniversitesi, Sosyal Bilimler Enstitüsü.

Bolay, S. H. (2004). Değerlerimiz ve günlük hayat. Değerler Ĕgitimi Dergisi, 1, 12-19. 
Büyükşahin-Çevik, G. (2007). Lise 3. sınıf ögrrencilerinin arkadaşlık ilişkileri ve benlik saygılarının bazı değişkenlere göre incelenmesi. Yüksek Lisans Tezi, Çukurova Üniversitesi, Sosyal Bilimler Enstitüsü, Adana.

Büyükşahin-Çevik, G. ve Çelikkaleli, Ö. (2010). Ergenlerin arkadaş bağl1lığı ve internet bağımlılığının cinsiyet, ebeveyn tutumu ve anne-baba eğitim düzeylerine göre incelenmesi. Çukurova Üniversitesi Sosyal Bilimler Enstitüsü Dergisi, 19(3), 225-240.

Canbay, H. (2010). Lise ögrencilerinin öznel iyi oluş düzeyleri ile sosyal beceri düzeyleri arasındaki ilişkinin incelenmesi. Yayımlanmamış doktora tezi, Dokuz Eylül Üniversitesi, Eğitim Bilimler Enstitüsü.

Cüceloğlu, D. (1992). İnsan ve davranışı. İstanbul: Remzi Kitabevi.

Çelik, Ş. (2008). Lise öğrencilerinin öznel iyi oluşlarının duygusal zeka açısindan incelenmesi. Yayımlanmamış yüksek lisans tezi, Selçuk Üniversitesi, Sosyal Bilimler Enstitüsü.

Çömez, T. (2014). Fiziksel engelli ergenlerde akran ilişkilerinin yaşam doyumu üzerine etkisi. Yayımlanmamış yüksek lisans tezi. İstanbul Üniversitesi, Sağlık Bilimleri Enstitüsü.

Delikara, İ. (2000). Ergenlerin akran ilişsileri ile suç kabul edilen davranışlar arasındaki ilişkinin incelenmesi. Yayımlanmamış yüksek lisans tezi, Ankara Üniversitesi Sosyal Bilimler Enstitüsü.

Demir, N. Ö., Baran, A. G. ve Ulusoy, D. (2005). Türkiye'de ergenlerin arkadaş ve akran grupları ile ilişkileri ve sapmış davranışlar: Ankara örneklemi, Bilig, 32, 83-108.

Dereli, E. ve Alpay, A. (2011). Orta öğretim öğrencilerinde empatik eğilim, işbirliği yapma karakter özelliği, insani değerler ve bu özellikler arasındaki ilişkiler. Değerler Eğitimi Sempozyumu bildiri özetleri kitabl içinde (s. 33). Eskişehir: Eskişehir Osmangazi Üniversitesi Eğitim Fakültesi. 
Diener, E. (1984). Subjective well-being. Psychological Bulletin, 95, $542-575$.

Diener, E. (2000). Subjective well-being: The science of happiness and a proposal for a national index. American Psychologist, 55, 34-43.

Diener-Biswas R., Diener, E. ve Tamir, M. (2004). The psychology of subjective wellbeing. Doedalus, 133(2), 18-25.

Dilmaç, B. (2007). Bir grup fen lisesi öğrencisine verilen insani değerler eğitiminin insani değerler ölçeği ile sınanması. Yayımlanmamış yüksek lisans tezi, Selçuk Üniversitesi, Sosyal Bilimler Enstitüsü.

Dost, M. T. (2005). Öznel iyi oluş ölçeği'nin geliştirilmesi: Geçerlik ve güvenirlik çalışması. Türk Psikolojik Danışma ve Rehberlik Dergisi, 3(25), 103-111.

Döğücü, F. (2004). Tosya ilçesinde farkl liselerde öğrenim gören ergenlerin arkadaş ilişkilerinin incelenmesi. Yayımlanmamış yüksek lisans tezi, Gazi Üniversitesi.

Dökmen, Z. Y. (1999). Bem cinsiyet rolü envanteri kadınsılık ve erkeksilik özellikleri Türkçe formunun psikometrik özellikleri. Kriz Dergisi, $7(1), 27-40$.

Dönmezer, İ. (1999). Ailede iletişim ve etkileşim. İstanbul: Sistem Yayınc1lık.

Duru, E. ve Türkdoğan, T. (2012). Üniversite öğrencilerinde öznel iyi oluşun yordanmasında temel ihtiyaçların karşılanmasının rolü. Kuram ve Uygulamada Ĕgitim Bilimleri, 12(4), 2429-2446.

Ekşi, H. (2003). Temel insani değerlerin kazandırılmasında bir yaklaşım: Karakter eğitimi programları. Değerler Ĕgitimi Dergisi, 1(1), 79-96.

Ercan, L. ve Eryılmaz, A. (2011). Öznel iyi oluşun cinsiyet, yaş grupları ve kişilik özellikleri açısından incelenmesi. Türk Psikolojik Danışma ve Rehberlik Dergisi, 4(36), 139-151.

Erden-İmamoğlu, S. (2009). Kişilerarası ilişkiler. İstanbul: Yeni İnsan. 
Erden, S. ve Ümmet, D. (2014). Examination of high school students' learned resourcefulness: A review of gender, parental attitudes, and values. International Online Journal of Educational Sciences, 6(1), $72-82$.

Eryılmaz, A. ve Yorulmaz, A. (2006, Eylül). Ergen öznel iyi oluşunun, özsayg1 ve iyimserlik eğilimi ile ilişkisinin incelenmesi. Ulusal 14. Psikoloji Kongresi, Hacettepe Üniversitesi, Ankara.

Fındıkçı, İ. (1998). Enformasyon bilgi toplumu dosyası, bilgi toplumunda eğitim ve öğretmen. Bilgi ve Toplum Dergisi, 1, 83-87.

Gülay, H. (2009). Okul öncesi dönemde akran ilişkileri. Balıkesir Üniversitesi Sosyal Bilimler Enstitüsü Dergisi, 12(22), 82-93.

Hortaçsu, N. ve Oral, A. (1991). Factors affecting relationships of Turkish adolescents with parents and same, Journal of Social Pschology, 131(3), 13-14.

İşleroğlu, S. (2012). Lise ögrrencilerinde öznel iyi oluşun benlik saygısı, sosyal yetkinlik beklentisi ve duygularl ifade etme eğilimine göre yordanması. Yayımlanmamış yüksek lisans tezi, Ege Üniversitesi, Sosyal bilimler Enstitüsü.

Kaner, S. (2000). Akran ilişkileri ölçeği ve akran sapması ölçeği geliştirilme çalışması. Ankara Üniversitesi Eğitim Bilimleri Fakültesi Dergisi, 33(1-2), 67-75.

Karasar, N. (2015). Bilimsel araştırma metodu. Ankara: Nobel Yayınları.

Köknel, Ö. (1997). İnsanı anlamak. İstanbul: Altın Kitaplar.

Malkoç, A. (2011). Öznel iyi oluş müdahale programının üniversite öğrencilerinin öznel iyi oluş düzeylerine etkisi. Yayımlanmamış yüksek lisans tezi, Marmara Üniversitesi, Eğitim Bilimleri Enstitüsü.

Mehmetoğlu, U. (2006). Küreselleşme, ahlâk ve değerler. İstanbul: Litera Yayıncilik. 
Özen, Y. (2005). Ergenlerin öznel iyi oluş düzeyleri. Yayımlanmamış yüksek lisans tezi, Hacettepe Üniversitesi, Sosyal Bilimler Enstitüsü, Ankara.

Santrock, J. W. (2011). Adolescence (14. bask1). NY: McGraw-Hill.

Sarı, E. (2005). Öğretmen adaylarının değer tercihleri: Giresun Eğitim Fakültesi örneği. Değerler Eğitimi Dergisi, 3(10), 73-88.

Saygın, Y. (2009). Üniversite öğrencilerinin sosyal destek, benlik saygısı ve öznel iyi oluş düzeylerinin incelenmesi. Selçuk Üniversitesi Ahmet Keleşoğlu Eğitim Fakültesi Dergisi, 28, 207-222.

Sayıl, M., Uçanok, Z. ve Güre, A. (2002). Erken ergenlik döneminde duygusu, gereksinimler, aileyle çatışma alanları ve benlik kavramı: Betimsel bir inceleme. Çocuk ve Gençlik Ruh Să̆gl̆ğ Dergisi, 9(3), 155-166.

Şahin, G. N. (2011). Üniversite öğrencilerinin kendini açma, öznel iyi oluş ve algıladıkları sosyal destek düzeylerinin karşılaştırılması. Yayımlanmamış yüksek lisans tezi, Dokuz Eylül Üniversitesi, Eğitim Bilimleri Enstitüsü.

Şimşek, D. (2010). YIBO ve ailesi yanında kalan ilköğretim sekizinci sınıf ögrencilerinin akran ilişskileri, sosyal destek algıları ve yaşam doyumlarının incelenmesi. Yayımlanmamış yüksek lisans tezi, Çukurova Üniversitesi, Sosyal Bilimler Enstitüsü.

TDK. (b.t.). http://www.tdk.gov.tr/index.php?option=com_gts\&arama=gts\&guid= TDK.GTS.58694219c39e34.33051407

Totan, T. (2008). Ergenlerde zorbalığın anne, baba ve akran ilişkileri açısindan incelenmesi. Yayımlanmamış Yüksek Lisans Tezi, Sosyal Bilimler Enstitüsü, Abant İzzet Baysal Üniversitesi, Bolu.

Uz-Baş, A. ve Siyez, D. (2006). “Akranları tarafindan kabul gören ve görmeyen ilköğretim okulu 4. ve 5. sınıf öğrencilerinin akran ilişkilerine yönelik algılarının incelenmesi”, $X V$. Ulusal Eğitim Bilimleri 
Kongresi, 13-15 Eylül 2006 Muğla.

Wilson, W. (1967). Correlates of avowed happiness. Psychological Bulletin, 67, 294-306.

Yel, S. ve Aladağ, S. (2009). Sosyal bilgilerde değerlerin öğretimi. M. Safran, (Ed.), Sosyal bilgiler öğretimi içinde (118-148). Ankara: PegemA Yayıncilik.

Yücel, N. (2009). Ergenlerin akran ilişkilerinde ve yalnızlık düzeylerinde evde internet kullanımının etkisinin incelenmesi. Yayımlanmamış yüksek lisans tezi, Ankara Üniversitesi, Fen Bilimleri Enstitüsü. 